Daniel J. Slive

\title{
INTERVIEW WITH BERNARD M. ROSENTHAL
}

The interviewer wishes to thank Ann Khaddar for her editorial assistance, Susan Campbell for her transcription, and the UCLA Oral History Program for support in the interview process.

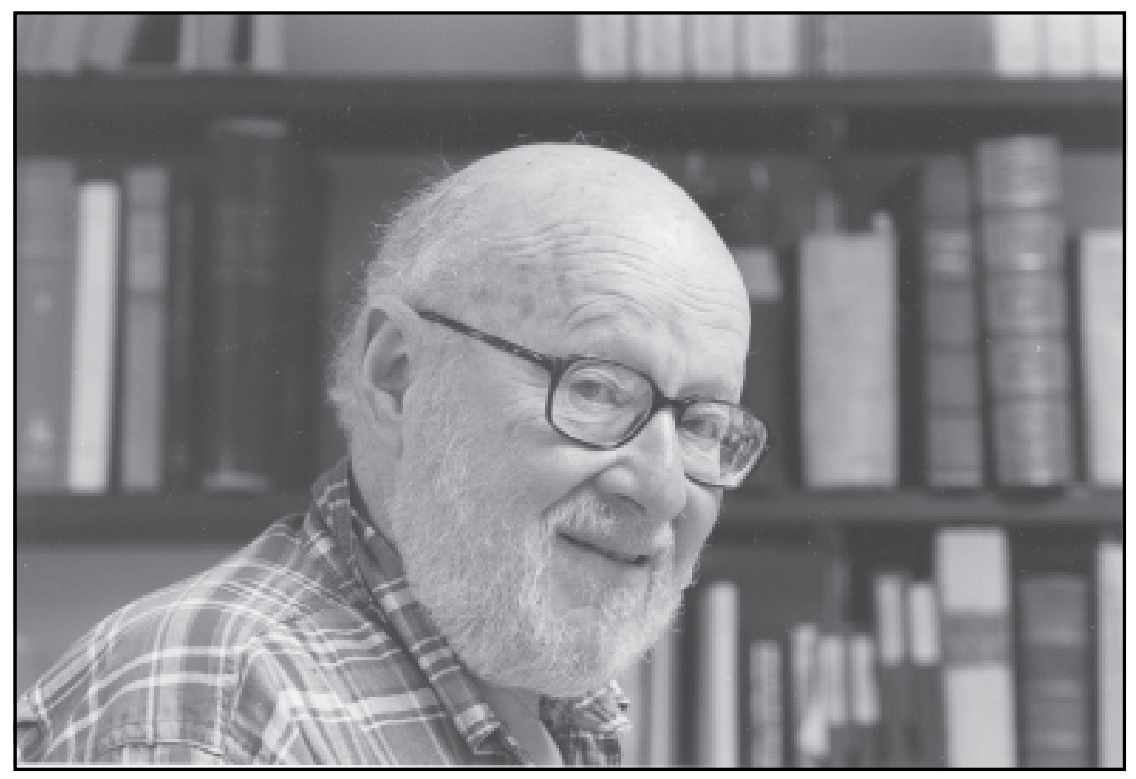

Bernard M. Rosenthal is an antiquarian bookseller based in Berkeley, California. His specialties include continental manuscripts and early printed books, the history of scholarship, bibliography, and paleography. Rosenthal was born in Munich in 1920 to a family with many connections to the book trade. His mother was the daughter of Leo Olschki, a renowned Italian bookseller. His father, who specialized in 
medieval and illuminated manuscripts, was the son of Jacques Rosenthal, a highly regarded seller of rare books in Munich. Other members of his extended family also were involved in the commercial book world as dealers, printers, and publishers.

After Hitler's rise to power, Rosenthal and his family left Germany and eventually immigrated to the United States in 1939. He received a bachelor's degree from the University of California at Berkeley in 1941 and served in the United States Army during World War II. He entered the trade in 1949 and began his own business in 1953. Since that time, he has issued more than 30 catalogues and served as president of the Antiquarian Booksellers' Association of America. He has delivered many lectures and informal talks, and published numerous book reviews and articles on medieval manuscripts, early printed books, and various aspects of the trade. He is the author of The Rosenthal Collection of Printed Books with Manuscript Annotations (New Haven, 1997), a catalogue of a collection he formed over three decades that was purchased en bloc by the Beinecke Library. In all of these endeavors as bookseller, collector, speaker, and author, Rosenthal has succeeded in his desire to serve and contribute to scholarship.

Many RBM readers may know that you come from a family of booksellers. Could you discuss your background and your own early involvement, if any, in the business?

Well, I do come from a long line of booksellers, but there never was such a thing as a family business. Each of my relatives had his or her own business, and although we collaborated, we never had the same firm and that's why we all remained on such good terms [laughter]. The kinds of books that my father and grandfathers sold were mostly early printed books, continental books, and medieval manuscripts. Around 1910 or 1912, my father, who was a Ph.D. in art history, 
entered his father's business in Munich, and decided to put the emphasis more on medieval miniatures and illuminated manuscripts, and introduced a fashion of making very scholarly, professional descriptions of these manuscripts. My grandfather in Italy also had more or less the same specialties, but both Jacques Rosenthal in Munich and Leo Olschki in Florence had huge businesses and you could say that they dealt in everything really, so long as it was antiquarian. ${ }^{1}$ My own early involvement with these firms, well, there really was no such thing because I was determined to escape from the family business, and in high school I got a liking for chemistry. I went to the University of California from 1939 to 1941, and I graduated with a bachelor's degree in chemistry. My involvement with the business didn't come until much later.

Although you were not directly involved in the business and, as you note, were trying to escape from it, could you talk about any early memories of the trade?

Do you mean memories that I have sitting at my grandfather's dinner table as a teenager? Well, I don't really have all that many memories, except I did hear the names of [J. Pierpont] Morgan and Philip Hofer and other great collectors mentioned at the dinner table, but I really wasn't all that interested. My involvement in the trade really doesn't come until much, much later, until about 1949 when I decided to become a bookseller. I was 29 years old at the time. I do know, speaking of my two grandfathers, that they lived a rather opulent lifestyle and obviously had made a huge success of their businesses.

1. For more information, including "A Genealogy of the Members of the Olschki and Rosenthal Families Active in the Antiquarian Book Business and Publishing," see: Bernard M. Rosenthal, "Cartel, Clan, or Dynasty? The Olschkis and the Rosenthals, 1859-1976," Harvard Library Bulletin 25, no. 4 (1977): 381-98. 
You referred to some of your early memories in a talk entitled "An Enemy Alien in Berkeley: Reminiscences of the War Years by a Slightly Bemused 39er."2

When I was asked to be a speaker at the Roxburghe Club [of San Francisco], I agreed, but only on the condition that I could speak about something that had nothing to do with books. They must have had trouble finding speakers, so they said, "Yes, that's fine." So I decided to talk about my first ten years in this country. I arrived in New York in 1939 just a month before the war broke out and, having heard so many wonderful stories about Berkeley from an Italian friend of mine who had just returned to Europe after spending a year in Berkeley, I decided to study there. So I took the train and went to Berkeley, and this in itself was an extraordinary experience for a 19-year-old, coming to this country and taking what was essentially a fiveday train ride through this enormous country. It's an impression that has stayed with me ever since. Also, I was treated very kindly by a customs officer in New York. When my mother and I came off the boat, the customs officer went through our bags and then he looked at me and he said, "Well, young man, do you expect to stay here and become a citizen?" And I said, "Yes, sir!" He took me aside and whispered in my ear so that my mother couldn't hear, "Young man, remember, in this country the woman is the boss." So that was my first introduction to American customs, and I was very surprised that a uniformed government official would speak so informally to a young man who had just arrived. In Berkeley, I worked awfully hard. I was rather disappointed because I expected that the European system would apply; namely, when you graduated from an Italian liceo, when Italians graduate from high school and then go to a university, they spend the first two years having a good time and not doing anything. And I found myself in Berkeley saddled with midterms and exams and I was very indignant about all this, having to work so hard, but I did. 


\section{What were you studying at that time?}

I was studying chemistry in Berkeley or, rather, I had a major in chemistry. I did not go to the College of Chemistry because I had other interests after all. So I studied some strange things that you could study in Berkeley. For instance, I took a year of Mongolian and took some other language courses, Russian and Spanish, but the majority of my courses were chemistry and physics, but I wasn't particularly good at them. I did graduate in December 1941 from Berkeley and then, of course, the war came, Pearl Harbor. Since I still had my German citizenship on paper, I and my family, in this case my parents and one of my two brothers, were declared enemy aliens. We were almost deported with the Japanese, but the order was then withdrawn, and only, in quotation marks, the Japanese were interned, which was bad enough. We were, however, placed under curfew and this made life pretty difficult. You can imagine how boring it would be for a college student to be home by eight every evening, but I managed to get a few interesting jobs. I knew I was going to be drafted sooner or later. One of the jobs I had was as a taxi driver, so, of course, even though I was an enemy alien, I was able to take sailors to their warships and pilots to the Alameda Air Station, and I knew pretty much what was going on in the Navy [laughter]. But life was pretty difficult-the funny thing was that my father was German and my mother was Italian so they represented both enemy alien elements, and the travel restrictions were kind of tough. You had to get a permit every time you wanted to drive more than ten miles, which was always granted, but it was a bother. For instance, every time my father wanted to see [San Francisco bookseller] Mr. Howell, he had to get a permit from the district attorney. Finally he got tired of it, and my parents moved back to New York where there were no such restrictions. Soon afterwards, my brother Felix and I were drafted and became GIs and came back, I came back in 1946, from the war. So briefly that's the enemy alien story. 
What did you do after the war before you went into the trade?

I was discharged in 1946. Then I was like ten million other GIs, looking for a job. It was kind of a difficult time, but I got a job for the [United States] government going overseas to Germany because of my knowledge of chemistry and German. The government needed chemists who could dig into German secrets and see if we couldn't appropriate a few of them, which we did. My own specialty was synthetic fuels. I was stationed in Germany for several months doing this work, and after we had finished our final report, I sort of began to think in terms of a civil service career. There was an opening in Berlin for somebody to act as French interpreter for the Allied Control Council, which was the four-power government that ruled Germany at the time. My French was very fluent due to a fiancée, which didn't work out, but still she was French speaking, and I had also lived in France before the war for a year. I passed the exam, and I became a French interpreter in Berlin. That was a very interesting experience because, you know, you sat with the Soviets, the French, the British, and the Americans; and it was a little bit like a caricature because the Soviets always did say "Nyet" [laughter]. It's quite true, but in 1948 when the Berlin blockade was imposed, the four-power government came to an end. There was no more need for interpreters, and I had signed up for a total of a year and still had six months to go. So they sent me to a post in Stuttgart that had nothing to do with French. It was an office for restitution, meaning that the Germans had stolen so many things in their occupied territories and the various governments then claimed them, and we were dealing with trucks and railroad cars and machinery and all that sort of thing. After coming home in 1949, after my two years in Europe were over, I decided that I really didn't like to work in large organizations and that I preferred something that I could do myself. I went to my father, who in the meantime had returned to Berkeley, and I said, "Dad, I'd like to try the book business." And he thought I had gone mad. I think it would amuse your readers to know that in 1949 he said to me, "First of all, you already have a brother in the book business. And second," he says, 
"there are no more good books and the few that are left, their prices are absolutely impossible." So that was 1949 , but I persisted and went ahead and took my apprenticeship. So that's when my involvement [in the trade] begins.

Can you tell us about your early experiences in the trade?

My father knew that he was not the person with whom I should apprentice-first of all, he was living in Berkeley. So he said, "If you want to learn the book business, go to our firm in Zurich." He had started a firm in Switzerland in 1920 called L'Art Ancien. It started in Lugano and then moved to Zurich, and that was a flourishing firm which was run by a very capable manager and several employees while my father lived in Berkeley. In 1949, I went to Zurich and started my apprenticeship at L'Art Ancien under the guidance of Mr. Alfred Frauendorfer, who was a very Teutonic sort of bibliographer, a stickler for details who required that every book had to be looked up in at least 10 reference books and bibliographies. I did learn a lot, but I also spent many, many years unlearning what I learned and giving the cataloguing of books a little more personal twist rather than this severe Teutonic system - what I called the bibliographical tyranny.

During my apprenticeship in Zurich, the firm Parke-Bernet Galleries in New York, the predecessors of Sotheby's, had a large sale, the Lucius Wilmerding sale. Mr. Swann, no relation to the Swann Galleries by the way, who was the head of the book department at the Parke-Bernet Galleries, sent a selection of books from the Wilmerding sale to Europe on exhibition to Geneva. And this is interesting; it should be recorded. This was the first attempt by an American auctioneer, postwar, to interest European buyers in an American sale. The dollar was, of course, extremely high at the time. European countries had barely begun to recover from the war, but he had this exhibition in Geneva and I went there to look at it and got to know Mr. Swann. And Mr. Swann said, "Well, as soon as you come back to America, you've got a job if you want and you 
can become a cataloguer." And this was wonderful, of course. I did take him up on that in 1951, after my two years in Zurich, which, by the way, also included a lot of seminars and courses at the University of Zurich. I took theology and especially medieval history. By that time I'd pretty much ditched chemistry in favor of the humanities, especially history.

By the time I returned to New York in 1951, I was married. I worked with Parke-Bernet Galleries for two years as a cataloguer. In 1953, barely two years after I was hired, I was let go, but it was not really as bad as it sounded. They had a bad year. The rare book business was a pretty chancey business at the time, and the word came down that 10 percent of the staff had to be fired and, of course, I was last in, so it was only right that I should be first out. They also knew that I wasn't going to stay forever. Mr. Swann and I remained on very cordial terms, I'm happy to say. A few months later, in March 1953, I found a parlor floor in a brownstone house at 71st and Madison and decided to take the plunge.

I was wondering if we could take a step back. Can you talk about some of the factors that led you to decide to enter the trade? You said that you were not interested in the bureaucracy of the government or large organizations, but why specifically the book business?

Yes, well, that may sound strange. I'm glad you asked that because why of all things pick such a weird business? Well, the fact is that many members of my family were in that business at the time. I had a brother in England who started his book business in 1936. I had several cousins and uncles in Italy who were antiquarian booksellers and publishers. I had my cousin in the Netherlands, the firm of Ludwig Rosenthal, which still exists, a cousin in Argentina and so on and so forth. So going into the book business was not as strange as it may sound, and it was something that all of a sudden I felt would be worth trying. And my father, by the way, said that, yes, I was a fool, but he 
had some incunables in the basement that needed collating [laughter]. So he said, "Well, start collating the incunables," and I did [laughter].

As a slight detour at this point, would you discuss "The Gentle Invasion," a lecture you gave at Columbia focusing on the continental émigré booksellers of the 1930s and 1940s and published by the Book Arts Press ${ }^{3}$ In particular, I was wondering if there is any facet of this story that you would explore further if you were to engage in a more extensive history of that aspect of the trade?

Being an immigrant myself, I soon met a very interesting group of booksellers in New York who had more or less all gone through the same experience I had-immigration from Germany and Austria. I was on very friendly terms with them, but, of course, also with others. But in New York, you couldn't help it if you were dealing in my specialty, which was then, as it is now, continental books. You couldn't help running into them and dealing with them and becoming friends with them. When Terry Belanger asked me to give the second [Sol M.] Malkin Lecture, I asked, "What do you want me to talk about?" And he replied, "Oh, anything you want." I never like that; I always want to be told precisely what they want me to say. But anyway it occurred to me that the one subject that had never really been properly covered was the topic of these émigré booksellers who settled in this country. I had known them all, most of them very well, and quite a few of them were still very much alive when I wrote this, and they were in the audience when I gave the lecture.

This was a lot of work to prepare; it took me almost a year to put this together. I started by sending a circular to all of them, a questionnaire which they answered, and then I put the facts together and tried to

3. - The Gentle Invasion: Continental Émigré Booksellers of the Thirties and Forties and Their Impact on the Antiquarian Book Trade in the United States (New York: Book Arts Press, School of Library Service, Columbia University, 1987). 
present a story as a whole. This being a lecture, I couldn't go into much detail, but you say quite rightly if I were to pursue this today, well, there are a number of ways one could do that. I would perhaps make a systematic study of their catalogues, which are still around. I would give far more biographical information than I could give in the course of the lecture and also speak a little more about their roles in the founding of the Antiquarian Booksellers' Association of America. Several of them were presidents. I can't include myself because I was not an immigrant bookseller, but I'm also a former president of the ABAA, so the Teutonic presence was rather strong [laughter]. So that is the thread I would pursue, although I must say the research on that would be a very, very laborious thing. The files [for this paper], by the way, have been sent to the University of Hamburg where there is an institute for the study of émigré art historians and other scholars. The papers are all there because, rather than keeping them in my basement, I thought I'd put them somewhere where people could use them.

\section{Could you talk a little bit about "The Gentle Invasion" itself?}

I called it "The Gentle Invasion" because that's precisely what it was, and the booksellers sort of dribbled in and began in the mid-1930s, especially Austrians. One Austrian became the greatest: H. P. Kraus came from Vienna. Some of them came via England. Thomas Heller, the history of science bookseller, came from England and then was very kindly supported by [the London firm] Maggs, who simply gave him a suitcase full of books on consignment to sell in America. There was a tremendous amount of cooperation and help and support. One of my questions in the questionnaire was: "Were any of the booksellers who came here given the cold shoulder by their American colleagues for fear of competition?" But not at all, not at all. They were all very well received. And the backgrounds of the people who came here were quite diverse, but they all tended to be very intellectual. Bill Salloch and his 
wife Marianne had Ph.D.'s in medieval history, and Ilse and Frederick Bernett were art historians, also with Ph.D.'s. If they didn't have official degrees, they all had very, very good schooling and a good bit of Kultur that you couldn't help getting when you went to a German or an Austrian school. And one of them was a publisher, Herbert Reichner. Basically their background was, as I said, intellectual, and they found that the antiquarian book business offered them a good opportunity to use their intellect to make a living.

\section{Maybe from here we can go back to the beginnings of your own firm.}

In 1953, I opened my own firm. I opened it under my own name and not in my grandfather's name or my father's name, and this is typical in my family. As I said, we all had our own firms and never really worked under one roof. So, I began. I had a great name-I mean the name Rosenthal was known worldwide in the antiquarian book tradebut I had no money. And I decided to go heavily into the scholarly book business and out-of-print scholarly books because I had enough medieval history and classical training by then to know which were the important editions. I was very familiar with the fields. I had, as a student, bought enough books so that I could start making my first list, which did very well. That was a good idea because it was a time when American libraries started becoming more conscious of classical and medieval studies and some of these books were extremely rare. I like to tell the story that the bibliography of Renouard on the Aldine press (Antoine-Augustin Renouard, Annales de l'imprimerie des Alde ou histoire des trois Manuce et de leurs éditions, Paris, 1834) was more expensive than some actual Aldines in the 1950s. It was not more expensive than the Hypnerotomachia Polifili, but these scholarly books had reached a very high level of value. I knew where the sources were and I went to Europe a lot. I knew where to buy them, especially in France and in 
Italy and in London, and if you look at my early lists and catalogues, they are very heavy in such reference books.

Just to clarify, here you are talking about modern printed works rather than early printed books?

Yes, exactly, modern reference books. One reason why I did this was that I wanted a broad base for my business and not to work like my father who, by the time he was in Berkeley and had been in business for about 40 years, sold maybe three manuscripts a year and that was his business. I said "never again" because I could remember how nervous he was when client number one didn't buy it and then Mr. [Lessing J.] Rosenwald didn't buy it. Then it was very difficult [laughter] to dispose of the books. I said I'm going to do it differently: I'm going to have a much broader base.

In reviewing some of your early catalogues and lists, I was pleasantly surprised to see a series devoted to reference works. Can you tell us about that?

Oh, I can indeed [laughs]. I still love out-of-print reference books and I still have some. When the utter scarcity of these reference books was recognized, the reprint industry began in earnest, and all the important reference books on medieval and renaissance history and scholarship were sooner or later reprinted. I found myself either fighting them or joining them. My expertise was in medieval and renaissance reference books and anything having to do with paleography, manuscript catalogues, and codicology. I studied the publishers' catalogues; I excerpted everything that pertained to the period from about 400 to 1600 , and I made catalogues of that, so that the historians and the classicists and the librarians could in one catalogue see whether a reference book was available for sale or not. I did quite well for a while, but instead of the 10 or 11 planned parts, I only published five because I found that the librarians all had their vendors. And so they read my catalogues and then ordered from a distributor. 
With whom they were dealing all along ...

Right, and I can't blame them. So I said "no more," and my last reprint catalogue was published after I moved my firm to San Francisco [in 1970]. Then I decided to abandon the field. It was fine while it lasted.

\section{Then you focused on earlier materials.}

I went full-time back into what I have always considered my expertise, which is medieval manuscripts and printed books of the fifteenth and sixteenth centuries. Also, books on the history of scholarship, which is a field that I like very much, history of bibliography, history of learning, and I went into that. Then I became financially a little more secure. I was able to put aside some books that interested me particularly, mainly books that had manuscript annotations in them. Since I had acquired some expertise in the reading of medieval and renaissance handwriting, I thought that maybe I could add a new perspective to these books. In the early 1960s, I began putting aside some books, and saying, "Someday I'm going to make a catalogue of books with manuscript annotations." But I found that cataloguing them was absolute hell because of the difficulty of reading the text and also the difficulty of making a description, as you can imagine. It's easy to do a bibliographical, analytical description of a book, but when you start reading the manuscript annotations, that's a whole different thing. It took me many, many years to really gather enough courage to catalogue these books, and I did on and off work on them, trying to devise a system because there was no system for this sort of thing. Finally, I decided that it was best not to devise a system, but to simply make your description as if the book were just an ordinary printed book and then make a special section devoted solely to the manuscript annotations. And that's still probably the best way of doing it. ${ }^{4}$ 
Many years later, I finally said, "Now we have to do something." So in the 1980s, I began to catalogue seriously and this was to be my catalogue number 34. By the time I had finished it, had all the photographs taken, I thought this may be something new in an antiquarian bookseller's catalogue. That's one thing that had never been done before. But then Robert Babcock came to see me from [Yale University's] Beinecke Library, and he saw the books and he bought them. I was absolutely flabbergasted. I didn't even have a price for them or anything.... And then we agreed that with the collection he would also get my catalogue as far as it had been completed, and it was almost complete except for some indices. But Bob is a scrupulous Latinist and a scrupulous classical scholar and, thank God, he went over my transcriptions of Latin and Greek text and corrected them. From a bookseller's catalogue, this had now become a work of real scholarship, and he also added several indices for provenance and printers. I must say that the publication is very handsomely printed and far beyond my expectations and, needless to say, Bob Babcock and I have remained very good friends ever since. ${ }^{5}$

Can you discuss in a little more detail the process of putting this collection together? Were there certain types of annotations or certain types of materials in which you were particularly interested?

This was, after all, supposed to be a bookseller's catalogue with emphasis on manuscript annotations. Sure, I would have liked a little more balance, for instance, more history of science. But I more or less bought what I could get and what I could afford not to sell for a while. If you look at my earlier catalogues, even one of the 1960s, I have lots of annotated books in them; and in one catalogue I even called the

5. Rosenthal, The Rosenthal Collection of Printed Books with Manuscript Annotations: A Catalogue of 242 Editions Mostly before 1600, Annotated by Contemporary or Near-contemporary Readers (New Haven, Conn.: Yale University Press, 1997). 
reader's attention to these manuscript notes, but that failed. It sank like a stone [laughs]. The way I put this collection together was rather haphazard, and as I think I said before, I simply took anything that looked interesting with interesting manuscript annotations and put it aside with the intention of cataloguing it some day. Also, they had to be books that I could afford not to sell but hang onto for 10 or 20 or 30 years, whatever it would take. That explains something that you might call the imbalance in my catalogue. There are 20 editions of Cicero, but there are very few in the history of science or in the history of botany or whatever, because this was meant as a bookseller's catalogue. I never had the intention at the time of forming what you would call a wellrounded collection. So if I had to do it over again, I would pay a little more attention to covering more fields than just the ones here.

But this does represent, in its very imbalance, the types of books that were most often annotated-obviously, the Leipzig school books and the Parisian editions of Aristotle and that sort of thing, where [with] other books ... it was not quite that common to have annotations in those. So by the time I had enough books accumulated, I felt that simply they had reached a critical mass and I could no longer afford not to catalogue them. I devised this sort of non-method of cataloguing them, simply saying what I thought was interesting in these notes. Sometimes there were notes that I was unable to read, but what I kept in mind always, and that's something that runs through all my career, is service to scholarship. I was never what you might call a rabid bibliophile. I love to see a book with beautiful wide margins, uncut and untouched. But the grubby book that has been handled and that has thumb marks in it that somebody annotated or otherwise left evidence of reading is really much more attractive. This is especially where my French bibliophile friends and I don't quite agree. But service to scholarship always has been very much in the forefront of my dealings, in the incunables and in the sixteenth-century books that I have sold. Libraries have always been my main customers, or if not libraries, 
then at least people who then gave the books to a library. So I'm very pleased to think of this as a contribution to scholarship.

The same can be said of my collections of paleographical specimens, the idea being that students of medieval history, and especially of paleography, should study not from Xeroxes or facsimiles but should actually be able to handle and to feel the paper and the parchment. In those days, it was still possible to put together collections illustrating the development of handwriting from the middle ages to about 1550, and there are about six or seven such collections. I think they've influenced the study of paleography. The furthest one away is in Japan, and several others are scattered in American libraries. And I do think that with the annotated books I have achieved this aim of giving scholars something to bite into for some original research.

\section{What are some of the research potentials for the annotated books?}

The potential for research is mainly to get a very vivid idea of the readers of the period, even when they're not identified, and most of them are not yet identified. I think someday a lot of them will be identified when we gather enough specimens. But if you want to write the history of pedagogy or a history of scholarship in the Renaissance, you can no longer ignore looking at the early editions of the classics or the early editions of Erasmus or the Bible. You can no longer ignore the annotated copies of these things, and the annotated copies are not rare. They're everywhere, except that nobody has ever really looked at them, and I think maybe it's because a lot of people were scared. They're hard books to work on, but I think enough scholars now are taking up the challenge.

These annotated books fit very much into contemporary scholarship examining the history of reading and the history of the 
book, but when you first started gathering them together, there was a little different point of view about these books.

Yes, but most of these books, let's face it, a lot of them are grubby looking. You know, you have an incunable that's been pawed and handled and maybe has some ink corrosion, or a beautiful sixteenthcentury book that has marks, censorship marks or something. So these books are by and large aesthetically no big thing, no big deal, which also made them affordable to me by the way. When I started doing this, unbeknownst to me, there was [Robin] Alston in London and there were several other people who were beginning to take manuscript annotations seriously. ${ }^{6,7}$ Somehow, as these things often happen, this was in the air, and I just happened to be among the booksellers. Perhaps among booksellers I was probably the first to see the potential in these things, but there were lots of scholars who were also working at the same time. By now it's become sort of an in subject in academia, complete with colloquia and publications and so on and so forth. I was very pleased to be invited to a colloquium on annotated books at the Università Cattolica in Milan two years ago at which I participated. So, as I say, it's now become a respectable subject. Even booksellers now mention manuscript annotations with less disdain than they did before. They used to be looked at as things that spoiled the book, you see.

You mentioned being active at conferences, and you also have an extensive list of publications. Can you describe your current and future projects, including any upcoming catalogues from the firm?

6. R. C. Alston, Books with Manuscript: A Short-title Catalogue of Books with Manuscript Notes in the British Library, Including Books with Manuscript Additions, Proofsheets, Illustrations, Corrections, with Indexes of Owners and Books with Authorial Annotations (London: British Library, 1994).

7. See: Roger E. Stoddard, Marks in Books, Illustrated and Explained (Cambridge, Mass.: Houghton Library, Harvard University, 1985); and —, "Looking at Marks in Books," in Roger E. Stoddard, A Library-Keeper's Business (New Castle, Del.: Oak Knoll, 2002). For further reading, see: "Marks in Books: Proceedings of the 1997 BSA Conference," Papers of the Bibliographical Society of America 91, no. 4 (1997). 
I'm not so sure about catalogues. I'm sort of toying with the idea, but I find myself continuing to work with annotated books. I have a very small inventory by now, but all the books have some distinguishing mark, and that distinguishing mark happens to be manuscript annotations. And I find it now, as then, just as difficult and time-consuming to describe them properly, but I enjoy it. I would like to continue a little more with the buying and selling of medieval text manuscripts. Again, there is this idea that text manuscripts are probably more interesting for the history of scholarship, of textual scholarship, than are the beautiful illuminated manuscripts and the Books of Hours. But they've become so rare and so expensive that I think my chances of still finding a reasonable number of such manuscripts are practically hopeless because there's a tremendous amount of competition. They all end up at major auctions. So I think my future plan will be to write more about annotated books, but I have a couple of other plans. I did write a substantial article on the history of the formation of incunabula collections in the United States about a year and a half ago. Unfortunately, there were some awful mistakes in it, and I intend to revise and expand it and to make a monograph out of it. So that's one project I'm working on now. One other small project is a contribution to a festschrift for a friend of mine. In the course of the years, I've handled some books that have manuscript instructions for the bookbinderthey're very brief-and I think I'll write a little article about what they say and how owners instructed their bookbinders to bind books. So these are the projects for the time being. I also read much professional literature; I subscribe to scholarly journals. But now I think the time is coming for a little more Harry Potter [laughter] than scholarship.

Looking back, particularly over the years you've been in the trade, do you have any comments about the changes you've seen? When you went into the trade, your father told you that there were no more good books out there. 
In a way, he was right because some of the things that my father handled were Carolingian manuscripts in ivory bindings, and those were not around anymore by 1949. But first of all, let me talk a little bit about the changes I've witnessed. There were quite a lot of them in the activity of the ABAA, of which I've been a member since 1955. It was founded in 1948, so I've been a member practically forever, and the association has become very respected and respectable. The association made possible the rise of the book fairs-I was in on the first book fair in New York City in 1961. We had great misgivings and none of us ever dreamed that book fairs would become such an extraordinarily important part of the market. In the early years, we could hardly scratch together enough booksellers to pay for the rent. Nowadays, all you have to announce is there's a book fair in Los Angeles and it's oversubscribed the next day. So this was one great development that I find very important.

To connect with "The Gentle Invasion," one of the points I make is that very few of the offspring of these booksellers have remained in the trade, but culturally many of the younger scholarly American booksellers are the heirs of these [émigré booksellers]. I find that there's a tremendous amount of bibliographical and scholarly expertise in the newer generation of booksellers. I'm not at all the person who says that they don't make them like they used to. I say they make them much better than they used to when it comes to really knowing their reference works and their bibliographies. So I feel very positive about the future of the trade, and if one fine day there are no more medieval manuscripts or there are no more books printed before 1470, well then, there will be lots of other books that you can collect. I think that the rare book trade will pretty much always be with us. Of course, the greatest development, which came a bit late for me to take full advantage of it, is the Internet, but I think again the Internet is a quantitative change. It's an enormous change, but qualitatively, you know, you still have to know how to describe a book and you still have to know how to go about collating it and presenting it properly. But, of course, the bibliographical means that we now have of accessing major 
library catalogs have made this much easier. The computer is here to stay, but underneath it the qualities, the ethical qualities, remain the same. So, future, positive! 